\title{
Fiscaoeconomia
}

Journal Homepage: dergipark.gov.tr/fsecon

\section{Measuring Quality of Governance in Turkey: A Composite Governance}

\section{Index}

\section{Türkiye'deki Yönetişim Kalitesinin Ölçümü: Kompozit bir Yönetişim Endeksi}

Onur POLAT ${ }^{1}$

Article Info

Article History:

Date Submitted: 05.11.2019

Date Accepted: 08.01.2020

Jel Classification:

C01, C51, G18

Keywords:

Worldwide Governance

Indicators,

Good Governance,

Principal Component

Analysis
Abstract

In this study, we analyze the quality of governance in Turkey by using worldwide governance indicators (WGIs), namely, voice and accountability (VA), political stability and absence of violence (PV), government effectiveness (GE), regulatory quality (RQ), rule of law (RL), and control of corruption (CC) which aggregate 6 dimensions of governance. In that regard, we employ principal component analysis (PCA) to construct a composite governance index (CGI) for Turkey over the 2002-2017 period. We find that the CGI creates proper signals to both economic and political disequlibriums observed in the post-2001 financial crisis era. Our findings underline an effective regulatory framework for monitoring the quality of governance and accordingly suggests the CGI as a policy tool.

\section{Introduction}

Concretely, "good governance" with its ingredients has been a cornerstone for sustainable development. In this context; scholars, policymakers and authorities have overwhelmingly focused on governance relevant policy tools both empirically and theoretically. Even though there was limited set of empirical indicators of governance initially, the growing interest in gauging governance by policy-relevant indicators has intented scholars to analyze more purified and policy-relevant governance indicators (Kaufmann and Kraay, 2007:2). Eventually, governance indicators have overwhelmingly drawn attention by both scholars and policymakers (Gisselquist 2014).

According to the 2015/16/17 Global Transparency International's Global Corruption Barometer, bribes are common for accession to the public services, and $57 \%$ of people believe

\footnotetext{
${ }^{1}$ Dr.Öğretim Üyesi, Bilecik Şeyh Edebali Üniversitesi, İiBF, Maliye Bölümü, opolat62@ yahoo.com.
} 
that their government is doing badly (Transparency International, 2017). In line with that, measuring governance has drawn attention by both developing and advanced countries.

Since the late 1990s the literature has been curious on measuring governance by policyrelevant indicators and accordingly, a literature has proliferated within a project, named Worldwide Governance Indicators (WGI) ${ }^{2}$. "The WGI are obtained from 31 data sources provided by 25 different organizations" (Kaufmann, Kraay and Mastruzzi, 2007:1). The WGI aggregate six dimensions of governance over 200 countries annually and measure the quality of governance.

In an attempt to analyze the quality of governance in Turkey, we construct a composite governance index for Turkey over the 2002-2017 period. In this context, we employ Principal Component Analysis (PCA) to aggregate a composite index by 6 dimensions of the WGI, namely, voice and accountability (VA), political stability and absence of violence (PV), government effectiveness (GE), regulatory quality $(R Q)$, rule of law $(R L)$ and control of corruption $(C C)$. To our knowledge, this study is the first attempt to construct such a composite index to gauge the quality of governance in Turkey.

The rest of the study is as follows: Section 2 reviews the related work addressing the research question. Section 3 describes the data and the methodology of the study. Section 4 constructs the composite governance index for Turkey and discusses the dynamics of the index. Finally, Section 5 concludes the study.

\section{Literature Review}

Over the last three decades the notion of 'governance' has drawn attention by policymakers and scholars from different disciplines, such as political science, public administration , and economics. Even though there is no consensus on the definition of governance, relevant studies have claimed some stylized facts that reflect the term. A pioneer study among them states that governance relates to "interdependence between organizations, resource-exchange, game-like interactions between network members and autonomy from the state" (Rhodes, 1999:1246). Spragia (2000:243) underlines that governance has been constrained by persistent strains between the market and the state during the 19th and 20th centuries. Bevir (2009:3) visions that governance refers to "changes in the nature and role of the state following the public sector

\footnotetext{
${ }^{2}$ See Kaufmann, Kraay and Zoido-Lobatón (1999a,b) and (2001), and Kaufmann, Kraay and Mastruzzi (2004, 2005, 2006a, 2006b, and 2010)
} 
reforms of the 1980s and 1990s". According to Stoker (2011), local governments sustain the most powerful role in governance.

Despite the notion 'good governance' is conceptually complex, an extensive number of studies have attempted to measure the quality of the governance. Williams and Siddique (2008) classify existant indicators into 'objective political instability indicators' and 'subjective country expert ratings'. According to the authors, objective indicators are mainly driven by facts regarding violence and political instability. On the contrary, subjective indicators stem from expert judgments or survey data.

UNDP (2007) conteptualizes governance indicators based on what is being measured, namely; input/rights/commitment/de jure, process/responsibility/de facto, and output/outcome/enjoyment/performance/de facto. Indicators in the first group reflect to commitments by the countries, the second group covers indicators "whether parties were taking action to fulfil their responsibilities and commitments" and the third group comprises of "data about the number of people enjoying their rights and figures about those who are not enjoying their rights" UNDP (2007:10).

Among policy-relevant governance indicators, the WGIs are commonly used and associate 6 dimensions of governance, namely: Voice and accountability (VA), Political stability and absence of violence (PV), Government effectiveness (GE), Regulatory quality (RQ), Rule of law (RL) and Control of corruption (CC). These indicators are constructed corresponding to three areas, such as the process by which governments are selected, monitored, and replaced (VA and PV), The capacity of the government to effectively formulate and implement sound pworld olicies (GE and RL) and The respect of citizens and the state for the institutions that govern economic and social interactions among them (Kaufmann, Kraay and Mastruzzi, 2010:4). The existant literature on WGIs are published through the Worldwide Governance Indicators Project (Kaufmann, Kraay and Zoido-Lobatón (1999a,b) and (2001), and Kaufmann, Kraay and Mastruzzi (2004, 2005, 2006a, 2006b, and 2010).

\section{Data and Methodology}

\subsection{Data}

Our data set consists of governance indicators, namely, voice and accountability (VA), political stability and absence of violence (PV), government effectiveness (GE), regulatory quality (RQ), 
rule of law (RL) and control of corruption (CC) for Turkey covering the 2002-2017 period. Governance indicators are obtained from the World Bank ${ }^{3}$.

\subsection{Model}

Our model consists of following steps:

1. Scaling and normalizing WGIs

2. Identifying principal components using normalized WGIs obtained in the first step

3. Constructing composite governance index for Turkey by weighted average of principal components ${ }^{4}$.

\subsection{Principal Component Analysis}

"Principal component analysis (PCA) is a mathematical procedure that uses an orthogonal transformation to convert a set of observations of possibly correlated variables into a set of values of linearly uncorrelated variables called principal components" (Jain and Shandlia, 2013: 373).

According to Abdi and Williams (2010:434), the goals of PCA are:

1) "Extract the most important information from the data table";

2) "Compress the size of the data set by keeping only this important information";

3) "Simplify the description of the data set";

4) "Analyze the structure of the observations and the variables"

In PCA, the components are identified by singular value decomposition (SVD) of data matrix $\mathrm{X}$ given as follows:

$$
X=P \Delta Q^{T}
$$

Where $Q$, loading matrix, represents the coefficients of the linear combinations to compute factor scores.

In line the above formulation, $I \times L$ factor scores matrix, $F$, is obtained as follows:

$$
F=P \Delta
$$

\footnotetext{
${ }^{3}$ Governance indicators have been collected from the www.govindicators.org web site.

${ }^{4} \mathrm{R}$ open source program is used to employ PCA analysis.
} 


\section{Results}

\subsection{Dynamics of WGIs}

In the first step, we visualize dynamics of WGIs for Turkey over the 2002-2017 period. Figure 1 exhibits governance indicators reflects to 6 dimensions, namely, voice and accountability (VA), political stability and absence of violence (PV), government effectiveness (GE), regulatory quality (RQ), rule of law (RL) and control of corruption (CC) between 2002 and 2017.

Figure 1. Dynamics of WGIs for Turkey in 2002-2017

\section{Governance Indicators}

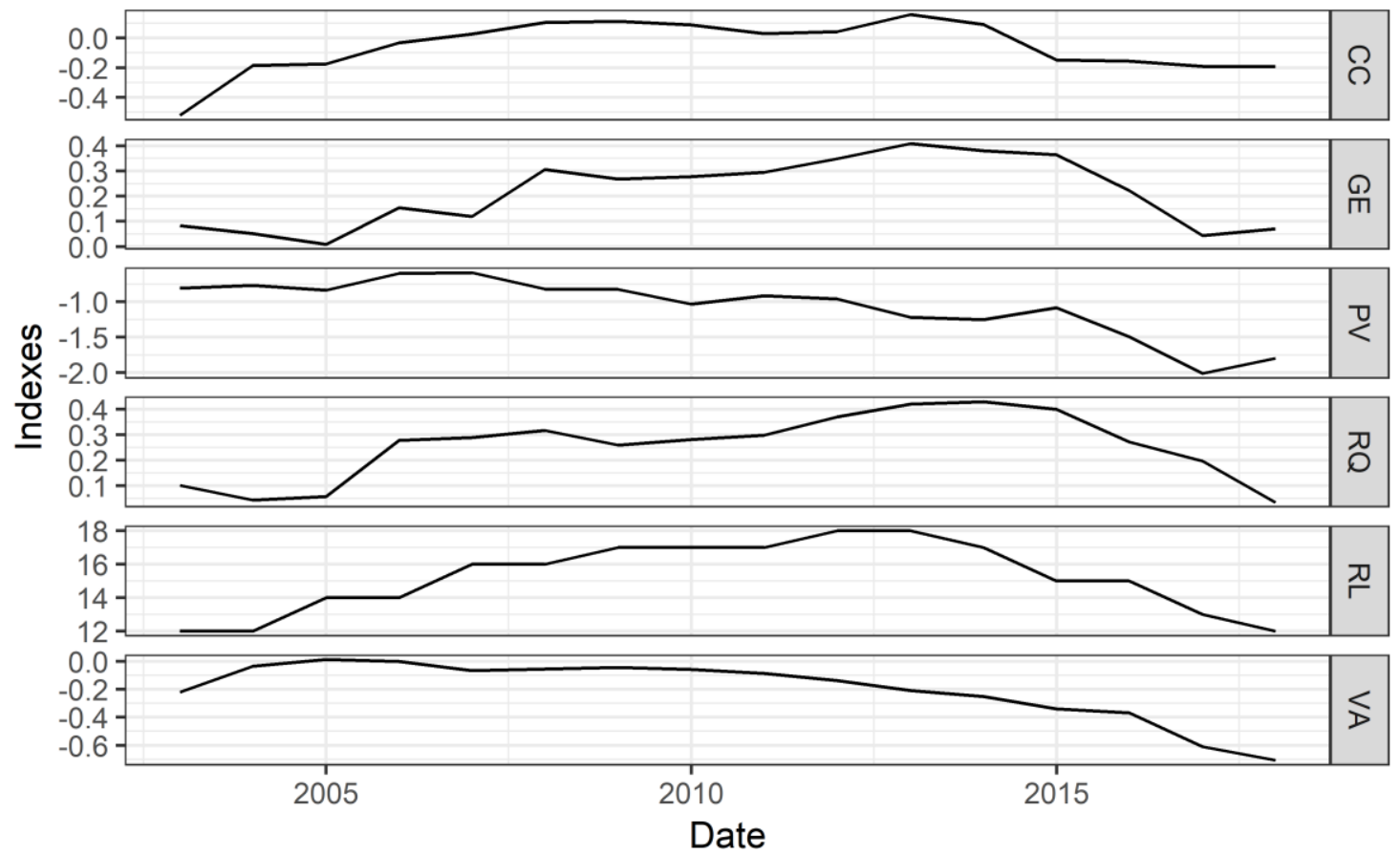

As seen in Figure 1; control of corruption, government effectiveness, regulatory quality, and rule of law tend to have an increasing trend between 2005 and 2012-2013, sharing a common pattern. Control of corruption, government effectiveness, and rule of law reach their peak values at around 2012, yet regulatory quality reaches its peak value in 2013.

As for the political stability and absence of violence (PV) and rule of voice and accountability (VA) indicators, the two series plunge between 2006 and 2017. The PV reaches its peak value at around 2006 (-0.59) and drops gradually till 2016 and reaches its minimum 
value (-2.01). On the other hand, the VA surges between 2002 and 2004 and reaches to its peak value (0.01). Afterward, it slightly escalates between 2004 and 2008, and sharply falls in the 2008-2017 period.

\subsection{Composite Governance Indicator}

In the second step, we carry out the PCA using 6 governance indicators to detect common factors that represent 6 dimensions. Table 1 presents the PCA results.

Table 1. PCA Results

\begin{tabular}{|c|c|c|c|c|c|c|}
\hline & PC1 & PC2 & PC3 & PC4 & PC5 & PC6 \\
\hline Standard deviation & 1.89670 & 1.32890 & 0.62672 & 0.32818 & 0.30100 & 0.21230 \\
\hline Proportion of Variance & 0.59960 & 0.29430 & 0.06546 & 0.01795 & 0.01510 & 0.00754 \\
\hline Cumulative Proportion & 0.59960 & 0.89400 & 0.95941 & 0.97736 & 0.99250 & 1.00000 \\
\hline
\end{tabular}

As presented in Table 1, the first two components explain almost $90 \%$ of the variance in the PCA.

Figure 2 exhibits screeplot of the first 6 principal components.

Figure 2. Screeplot of the first 6 PCs

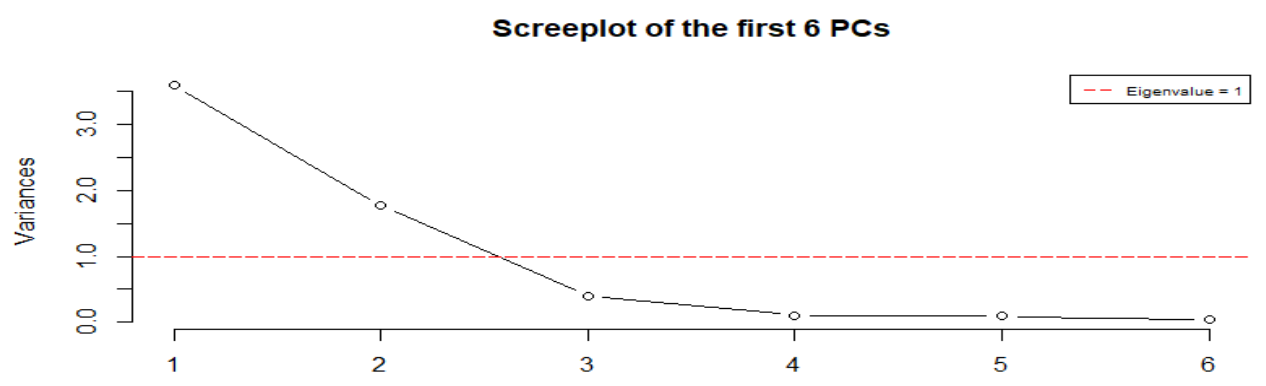

According to Figure 2, the first two components capture most of the information. Using the Kaiser rule, we pick the first two components to construct the composite governance indicator.

In the next step, we construct the composite government index using weighted average of the first 2 PCs according to following formula:

$$
\begin{aligned}
C G I= & P C 1 \times \text { Amount of explained variance by } P C 1(0.5996)+ \\
& P C 2 \times \text { Amount of explained variance by } P C 2(0.2943)
\end{aligned}
$$

Figure 3 depicts the Composite Governance Index (CGI) for Turkey in the 2002-2017 period. 
Figure 3. Composite Governance Index for Turkey

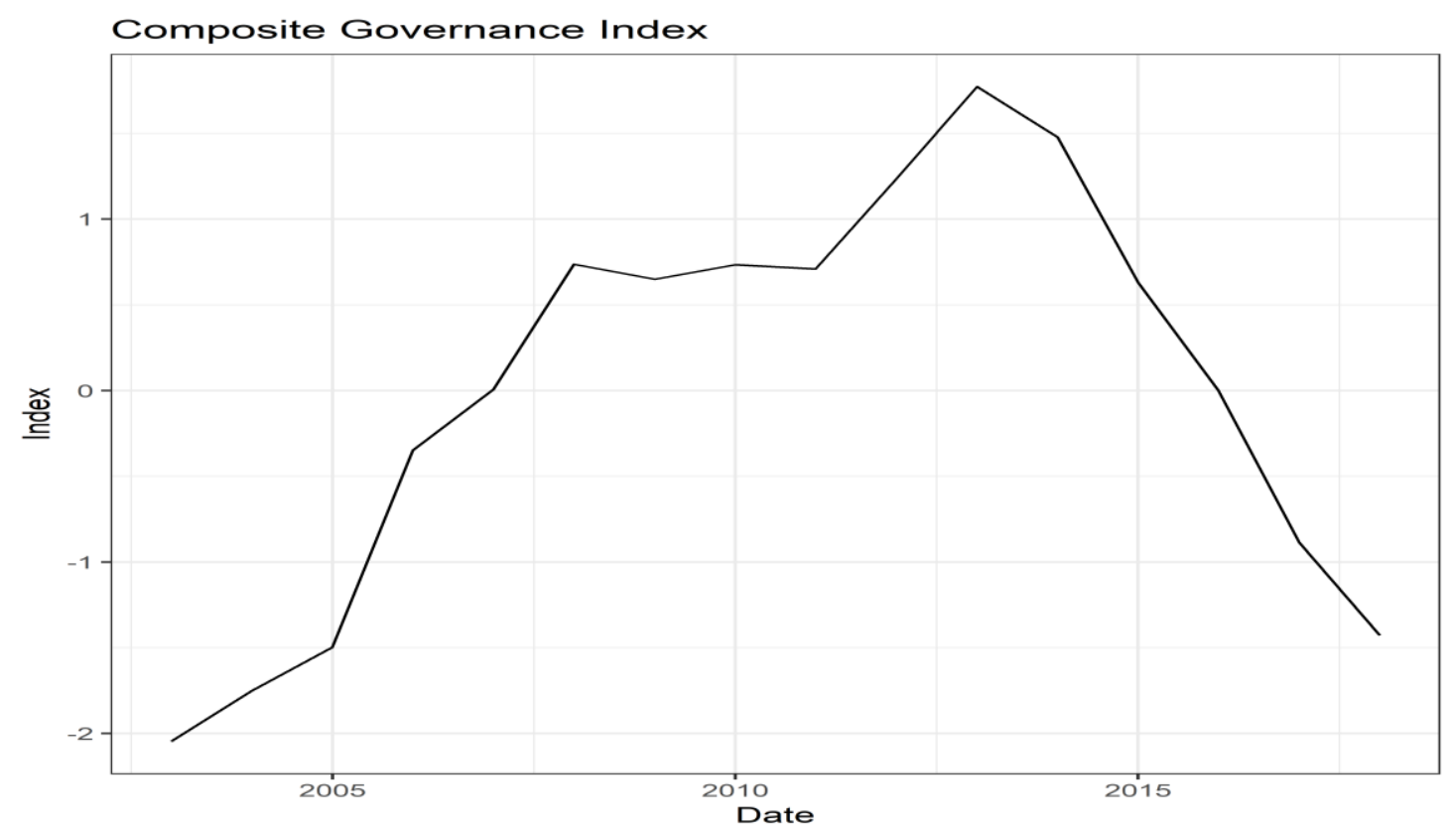

According to Figure 3, the CGI gradually elevates between 2002 and 2012 except for 2009 and 2011. This period corresponds to post-2001 financial crisis era, which characterized by relatively high GDP growth rates and dis-inflation except for 2009 (Erinç Yeldan and Ünüvar, 2016). Starting from 2012, the CGI dramatically falls from 1.77 to -1.43 in 2017 . As stated in (Erinç Yeldan and Ünüvar, 2016), Turkey has confronted with severe disequilibrium and increased external debt burdens since the second half of 2010s. Morever, Turkey's state institutions faced to failed coup d'etat and Turkey's financial stress significantly surged, accordingly (Polat and Ozkan, 2019). As a consequence, the dynamics of the CGI are robust and consistent with political as well as economic developments observed in the post-2001 period.

\section{Conclusion}

Despite there is no consensus on the term 'governance' owing to its conceptual complexity, it has gradually drawn attention by scholars and policymakers to achieve sustainable development. In that regard, "good governance" and/or "governance matters" have been brought forward and attempts have been made on measuring the quality of governance quantitatively by policy-relevant indicators. Among these attempts, the World Bank has developed worldwide governance indicators which correspond to 6 dimensions of governance, 
namely voice and accountability (VA), political stability and absence of violence (PV), government effectiveness (GE), regulatory quality (RQ), rule of law (RL) and control of corruption (CC).

In this study, we construct a composite governance index (CGI) for Turkey by employing principal component analysis. In this respect, we use worldwide governance indicators developed for Turkey (VA, PV, GE, RQ, RL, and CC) in the 2002-2017 period as inputs and construct CGI by the weighted average of the most important principal components. The dynamics of CGI are in line with the economic and political developments during the post2001 era.

The dynamics of CC, GE, RQ, and RL reveal that the indicators tend to increase in the 2005-2013 period, sharing a common trend. Besides, control of corruption, government effectiveness, and rule of law reach their peak values in 2012, while regulatory quality reaches its peak value in 2013. As for PV and VA, the two governance indicators plummet between 2006 and 2016, reach their minimum levels in 2016 and 2017, respectively.

We develop the CGI for Turkey using the first two common factors, which capture most of the information. The CGI significantly surges in the 2002-2012 period except for 2009. This period is also associated with post-2001 financial crisis era, where rapid high growth rates and dis-inflation take in place. However, the index dramatically plunges starting from 2012 and reaches its through in 2017. This last period covers political and economic disequilibriums such as failed coup d'etat, accordingly the CGI index creates proper signals to the economic and political developments occurred in that period.

Our work has important policy implications. Since 'good governance' has an important mission in sustaining development, policymakers need to build an effective regulatory framework for monitoring the quality of governance. In this context, the CGI tool could be helpful. 


\section{REFERENCES}

Abdi, H., \& Williams, L. J. (2010). Principal component analysis. Wiley interdisciplinary reviews: computational statistics, 2(4), 433-459.

Bevir, M. (2009). Key concepts in governance. Sage Publications Inc.

Erinç Yeldan, A., \& Ünüvar, B. (2016). An assessment of the Turkish economy in the AKP era. Research and policy on Turkey, 1(1), 11-28.

Gisselquist, R. M. (2014). Developing and evaluating governance indexes: 10 questions. Policy Studies, 35(5), 513-531.

Jain, P. M., \& Shandliya, V. K. (2013). A survey paper on comparative study between principal component analysis (PCA) and exploratory factor analysis (EFA). International Journal of Computer Science and Applications, 6(2), 373-375.

Kaufmann, Daniel, Aart Kraay and Pablo Zoido-Lobatón (1999a). “Aggregating Governance Indicators.” World Bank Policy Research Working Paper No. 2195, Washington, D.C.

Kaufmann, Daniel, Aart Kraay and Pablo Zoido-Lobatón (1999b). "Governance Matters." World Bank Policy Research Working Paper No. 2196, Washington, D.C.

Kaufmann, Daniel, Aart Kraay and Pablo Zoido-Lobatón (2002). “Governance Matters IIUpdated Indicators for 2000/01.” World Bank Policy Research Working Paper No. 2772, Washington, D.C.

Kaufmann, Daniel and Aart Kraay (2002). "Growth Without Governance". The World Bank.

Kaufmann, Daniel, Aart Kraay and Massimo Mastruzzi (2004). "Governance Matters III: Governance Indicators for 1996, 1998, 2000, and 2002”. World Bank Economic Review. 18:253-287.

Kaufmann, Daniel, Aart Kraay and Massimo Mastruzzi (2005). “Governance Matters IV: Governance Indicators for 1996-2004. World Bank Policy Research Working Paper No. 3630. Washington, D.C.

Kaufmann, Daniel, Aart Kraay and Massimo Mastruzzi (2006a). "Measuring Governance Using Perceptions Data", in Susan Rose-Ackerman, ed. Handbook of Economic Corruption. Edward Elgar.

Kaufmann, Daniel, Aart Kraay and Massimo Mastruzzi (2006b). "Governance Matters V: Governance Indicators for 1996-2005. World Bank Policy Research Department Working Paper No. 4012. 
FSECON POLAT, O. (2020)," Measuring Quality of Governance in Turkey: A Composite Governance Index”, Fiscaoeconomia, Vol.4(1), 51-60.

Kaufmann, D., \& Kraay, A. (2007). Governance Indicators: Where are we, where should we be Going?. The World Bank Research Observer 23: 1-30.

Kaufmann, D., Kraay, A., \& Mastruzzi, M. (2007). The worldwide governance indicators project: answering the critics. The World Bank.

Kaufmann, D., A. Kraay, and M. Mastruzzi. (2010). The Worldwide Governance Indicators: Methodology and Analytical Issues. World Bank Policy Research Working Paper 5430.

Polat, O., \& Ozkan, I. (2019). Transmission mechanisms of financial stress into economic activity in Turkey. Journal of Policy Modeling, 41(2), 395-415.

Rhodes, R. A. (2007). Understanding governance: Ten years on. Organization studies, 28(8), 1243-1264.

Sbragia, A. M. (2000). Governance, the state, and the market: what is going on?. Governance, 13(2), 243-250.

Stoker, G. (2011). Was local governance such a good idea? A global comparative perspective. Public administration, 89(1), 15-31.

UNDP. 2007. Governance Indicators: A Users' Guide. New York: United Nation Development Programme.

Transparency International (2017). People and Corruption: Citizens' Voices from Around the World. Global Corruption Barometer. Retrieved from https://www.transparency.org/whatwedo/publication/people_and_corruption_citi zens_voices_from_around_the_world

Williams, A., \& Siddique, A. (2008). The use (and abuse) of governance indicators in economics: a review. Economics of Governance, 9(2), 131-175. 